\title{
Hydroxychloride trace minerals have a positive effect on growth performance, carcass quality and impact ileal and cecal microbiota in broiler chickens
}

\author{
Sandra J. A. van Kuijk ${ }^{1 *}$, Yanming Han ${ }^{1}$, Ana Isabel Garcia-Ruiz ${ }^{2}$ and Ana Rodiles ${ }^{1}$
}

\begin{abstract}
Background: The objective was to study the effect of hydroxychloride trace minerals (HTM) on growth performance, carcass quality and gut microbiota of broiler chickens in comparison to sulphate trace minerals (STM). In total 1440 male Ross 308 day-old chicks were divided into 12 replicate pens with 30 birds each per treatment. Four different treatments were tested according to a $2 \times 2$ factorial study design, where the animals received a three phase diet containing either inorganic Zn from sulphates or Zn from HTM in high ( $80 \mathrm{mg} / \mathrm{kg} \mathrm{Zn}$ ) or low Zn dosage (20 mg/kg Zn). In all treatments $15 \mathrm{mg} / \mathrm{kg}$ Cu was added from the same mineral source as the Zn. Body weight and feed intake were measured on day 0, 10, 27 and 34, while carcass and breast meat yields were measured at the end of the study (day 34). In addition, high-throughput sequencing analysis was performed in digesta samples from ileum and cecum to study the gut microbiome (day 34).
\end{abstract}

Results: The results showed an improved $(P<0.05)$ body weight of broiler chickens fed HTM, regardless of Zn level, on day 27, while on day 34 this effect remained as a tendency $(P=0.0542)$. In the overall study period, birds fed HTM had a higher $(P<0.05)$ average daily gain and average daily feed intake when compared to birds fed STM. The mineral source did not affect the carcass characteristics, however, feeding $80 \mathrm{mg} / \mathrm{kg} Z \mathrm{n}$ resulted in a significantly higher $(P=0.0171)$ breast meat yield, regardless of source. High-throughput sequencing analysis of the microbiota revealed a higher microbial diversity in the ileum and cecum of HTM fed birds compared to STM fed birds. Taxonomical differences were mainly found in the cecum, specifically between the group fed high and low Zn levels from HTM. This correlated with the mineral contents observed in the cecal digesta. Comparing both groups fed $80 \mathrm{mg} / \mathrm{kg}$ Zn, the HTM group had more Streptococcaceae, Streptococcus, Clostridia, Weissella and Leuconostocaceae compared to the STM group.

Conclusions: HTM improved growth performance of broiler chickens; and the source and level of Zn modulated the gut microbiota communities in broilers differentially.

Keywords: Broiler chickens, Growth performance, Gut microbiota, Hydroxychloride trace minerals

\footnotetext{
* Correspondence: Sandra.van.kuijk@trouwnutrition.com

${ }^{1}$ Trouw Nutrition R\&D, P.O. Box 299, 3800, AG, Amersfoort, the Netherlands

Full list of author information is available at the end of the article
}

(c) The Author(s). 2021 Open Access This article is licensed under a Creative Commons Attribution 4.0 International License, which permits use, sharing, adaptation, distribution and reproduction in any medium or format, as long as you give appropriate credit to the original author(s) and the source, provide a link to the Creative Commons licence, and indicate if changes were made. The images or other third party material in this article are included in the article's Creative Commons licence, unless indicated otherwise in a credit line to the material. If material is not included in the article's Creative Commons licence and your intended use is not permitted by statutory regulation or exceeds the permitted use, you will need to obtain permission directly from the copyright holder. To view a copy of this licence, visit http://creativecommons.org/licenses/by/4.0/ The Creative Commons Public Domain Dedication waiver (http://creativecommons.org/publicdomain/zero/1.0/) applies to the data made available in this article, unless otherwise stated in a credit line to the data. 


\section{Background}

Zinc is an essential trace mineral for broiler chickens. Zinc has been proven to play a role in immunity, enzymatic processes and eventually in growth $[1,2]$. Therefore, Zn deficiency can cause major problems. To prevent a deficiency, it is a commercial practice to add $\mathrm{Zn}$ to diets at higher dosages than those advised for poultry by the National Research Council (NRC) [3]. Higher dosages in the diet will however result in more excretion of this trace mineral into the environment. Recently, the EFSA (European food safety agency) published guidelines about the importance of reducing the amount of heavy metals into the environment [4]. Thus, it is essential to reduce the amount of $\mathrm{Zn}$ added to broiler diets. As expected, reducing the dose in the diet will reduce the excretion into the environment [5]. Inorganic trace minerals in the form of sulphates have a lower bioavailability than other commercially available mineral sources [6]. Hydroxychloride trace minerals (HTM) are a good example of a more bioavailable mineral source in broilers compared to sulphate trace minerals (STM) [7]. In addition, HTM do have a unique crystalline structure that is not readily soluble at a $\mathrm{pH}$ above $4[8,9]$. Moreover, HTM are much less reactive in the feed than STM, and do not interact with antinutritional factors such as phytate $[10,11]$. In addition, the low solubility at higher $\mathrm{pH}$ suggests that the $\mathrm{pH}$ in the gastrointestinal tract may have a specific effect on the function of HTM. Both differences in solubility and reactivity between HTM and STM may result in different quantities and forms of $\mathrm{Zn}$ present in the different compartments of the gastrointestinal tract. It is also known that $\mathrm{Zn}$ is essential for several microbes [12], indicating that a different source and level of $\mathrm{Zn}$ available in the gut may influence the microbiota. Olukosi et al. [13] already showed a beneficial effect of HTM on growth performance and carcass quality in broiler chickens. The objective of the present study was to investigate the effects on growth performance, carcass and breast meat yield, and microbiota of broiler chickens fed STM or HTM in high and low Zn dosages in presence of $15 \mathrm{mg} / \mathrm{kg} \mathrm{Cu}$ of the same mineral source. With the above mentioned differences in solubility and bioavailability, we expected a larger contrast between high and low Zn levels in HTM fed birds compared to STM fed birds.

\section{Materials and methods}

\section{Animals and dietary treatments}

In total, 1440 newly hatched male Ross 308 broiler chicks were housed at the Poultry Research Facility of Trouw Nutrition, Casarrubios del Monte, Spain. The birds were randomly allocated into groups of 30 animals per floor pen $(3 \mathrm{~m} \times 1 \mathrm{~m})$ with 6 and $18 \mathrm{~h}$ of light/dark periods. Each pen provided $0.10 \mathrm{~m}^{2} /$ bird with wood shavings litter. Each group was randomly allocated to one of four treatments with 12 replicate pens each. The four treatments were applied according to a $2 \times 2$ factorial study design, in which two mineral sources of zinc (STM and HTM) were tested at two different zinc levels (high: $80 \mathrm{mg} / \mathrm{kg}$ and low: $20 \mathrm{mg} / \mathrm{kg}$ ), whereas to all diets $15 \mathrm{mg} / \mathrm{kg} \mathrm{Cu}$ was added from the same mineral source as the $\mathrm{Zn}$. Sulphate trace minerals source were added to the feed in the form of $\mathrm{Zn}$ sulphate (zinc sulphate monohydrate, Sigma-Aldrich, Saint Louis, MO, USA), and $\mathrm{Cu}$ sulphate (copper(II) sulphate pentahydrate, Sigma-Aldrich, Saint Louis, MO, USA). Hydroxychloride trace minerals were added at the same $\mathrm{Zn}$ (IntelliBond Z, Trouw Nutrition, The Netherlands) and $\mathrm{Cu}$ (IntelliBond C, Trouw Nutrition, The Netherlands) levels as for the sulphate minerals. The composition of the diets is shown in Table 1. The wheat-soybean meal diets were

Table 1 Feed formulation used in the three feeding phases

\begin{tabular}{|c|c|c|c|}
\hline Ingredient, \% & Starter & Grower & Finisher \\
\hline Wheat & 53.511 & 65.490 & 67.949 \\
\hline Soya bean meal & 29.149 & 25.267 & 22.554 \\
\hline Soya oil & 6.969 & 5.177 & 5.819 \\
\hline Wheat bran & 5.000 & & \\
\hline Potato protein & 1.459 & 1.334 & 1.400 \\
\hline Calcium-carbonate fine & 1.206 & 0.566 & 0.455 \\
\hline Monocalcium phosphate & 1.072 & 0.553 & 0.261 \\
\hline Vit-min premix without $\mathrm{Zn}$ and $\mathrm{Cu}^{1}$ & 0.500 & 0.500 & 0.500 \\
\hline Sodium bicarbonate & 0.256 & 0.221 & 0.210 \\
\hline$D L$-Methionine & 0.249 & 0.230 & 0.213 \\
\hline L-Lysine $\mathrm{HCl}$ & 0.224 & 0.240 & 0.215 \\
\hline Salt ( $\mathrm{NaCl})$ & 0.166 & 0.166 & 0.174 \\
\hline Xylanase & 0.100 & 0.100 & 0.100 \\
\hline Phytase & 0.100 & 0.100 & 0.100 \\
\hline L-Threonine & 0.038 & 0.056 & 0.051 \\
\hline Calculated AME broilers, kcal & 2850 & 2925 & 3000 \\
\hline \multicolumn{4}{|l|}{ Analysed nutrients } \\
\hline Crude protein, g/100 g & 21.5 & 19.6 & 18.9 \\
\hline Crude ash, g/100 g & 5.0 & 3.8 & 3.5 \\
\hline Crude fiber, g/100 g & 2.8 & 2.7 & 2.6 \\
\hline Moisture, g/100 g & 8.4 & 8.8 & 8.7 \\
\hline $\mathrm{Ca}, \mathrm{g} / 100 \mathrm{~g}$ & 0.90 & 0.58 & 0.48 \\
\hline$P, g / 100 \mathrm{~g}$ & 0.61 & 0.46 & 0.38 \\
\hline
\end{tabular}

${ }^{1}$ Provided per $\mathrm{kg}$ of final feed: $0.65 \mathrm{~g}$ calcium, $90 \mathrm{mg}$ manganese oxide, $1 \mathrm{mg}$ potassium iodide, $0.25 \mathrm{mg}$ selenium (sodium selenite), $65 \mathrm{mg}$ iron (ferrous carbonate), 10,000 IU vitamin A, $2500 \mathrm{IU}$ vitamin $\mathrm{D}_{3}, 50 \mathrm{UI}$ vitamin E (all-rac-atocopherol-acetate), $2 \mathrm{mg}$ vitamin $\mathrm{K}_{3}, 2 \mathrm{mg}$ vitamin $\mathrm{B}_{1}, 6 \mathrm{mg}$ vitamin $\mathrm{B}_{2}, 4 \mathrm{mg}$ vitamin $B_{6}$ (pyridoxine hydroxychloride), $25 \mu \mathrm{g}$ vitamin $B_{12}, 40 \mathrm{mg}$ niacinamide, $10 \mathrm{mg}$ calcium $D$-pantothenate, $10 \mathrm{mg}$ pantothenic acid, $1 \mathrm{mg}$ folic acid, $150 \mu \mathrm{g}$ biotin, $300 \mathrm{mg}$ choline chloride, $0.61 \mathrm{~g}$ sepiolite, $0.75 \mathrm{mg}$ butylated hydroxyanisole (BHA), $8.25 \mathrm{mg}$ butylated hydroxytoluene (BHT),

$1.20 \mathrm{mg}$ ethoxyquin 
offered as pellets in three phases, with phase 1 being from day 0 to 10 , phase 2 from day 10 to 27 and phase 3 from day 27 to 34, according to the NRC requirements of the species [3]. The analysed mineral contents of the diets are shown in Table 2. Animals were fed ad libitum throughout the entire study period of 34 days.

At the end of the experiment, 6 animals per pen were selected based on average body weight and euthanized by cervical dislocation according to the guidelines of the Ethics Committee of Poultry Research Centre of Trouw Nutrition for the humane care and use of animals in research. Animal procedures were verified by the External Ethical Committee of "Hospital General Universitario de Ciudad Real", and approved by the Junta de Castilla-La Mancha Animal Welfare department as compliable with the RD 53/2013 of the 1st of February which establishes basic rules applied to protect animals used for research, and other scientific matters like teaching. The present study was approved by the Trouw Nutrition Animal Care Committee and followed recommendations of the Castilla-La Mancha Animal Welfare Department (Royal degree RD 53/2013), in compliance with the European Union guidelines for the care and use of animals in research (European Parliament, 2010). From the six birds selected per pen, five birds were used for carcass and breast meat yields and the remaining one was sampled for both the microbiota and mineral content. Samples were collected aseptically by opening the abdominal cavity with a sterile blade, the intestinal content (digesta) from the ileum and cecum was placed into a sterile tube until further analysis. All samples were immediately snap

Table 2 Analysed copper and zinc levels in the experimental diets (hydroxychloride trace minerals, HTM and sulphate trace minerals, STM) in high and low dosage

\begin{tabular}{lll}
\hline Diet & Copper, $\mathbf{~ g} \mathbf{g} \mathbf{k g}$ & Zinc, $\mathbf{~ g} \mathbf{g} \mathbf{k g}$ \\
\hline Starter phase 1 & 23 & 116 \\
STM high & 20 & 60 \\
STM low & 24 & 120 \\
HTM high & 22 & 60 \\
HTM low & & \\
Grower phase 2 & 22 & 114 \\
STM high & 22 & 56 \\
STM low & 22 & 118 \\
HTM high & 21 & 54 \\
HTM low & & \\
Finisher phase 3 & 21 & 112 \\
STM high & 22 & 52 \\
STM low & 22 & 117 \\
HTM high & 22 & 52 \\
HTM low & &
\end{tabular}

frozen on dry ice and then transferred to $\mathrm{a}-80^{\circ} \mathrm{C}$ freezer.

\section{Zootechnical parameters}

Body weight and feed intake was measured per pen at the start of the experiment at day 0 and at the end of each feeding phase at day 10, 27 and 34. The body weight and feed intake measures were used to calculate the average daily gain, the average daily feed intake and the feed conversion ratio (feed:gain). On day 34, the carcasses were weighted and both breast muscles were excised and weighted by qualified personnel. These weights were used to calculate carcass and breast yield, as the percentage of the live weight or the carcass weight, respectively.

\section{Mineral content of ileum and cecum digesta}

Zinc and copper content in the diets and in 1 ileal and 1 cecal digesta samples (from the same animal) per pen, resulting in 12 ileal and 12 cecal samples per treatment were analysed according to ISO (ANA-00281) using inductively coupled plasma-mass spectroscopy (ICP-MS) (Nexion 300D, Perkin elmer, Waltham, MA, USA) with an autosampler coupled (4DX, Elemental Scientific (ESI), Omaha, NE, USA). The chemicals used were nitric acid (67-69\%) and hydrochloric acid (34-35\%) of ultra pure grade for trace mineral analysis (VWR, Amsterdam, The Netherlands).

\section{DNA extraction, PCR and library preparation}

From the ileal and cecal digesta $200 \mathrm{mg}$ of samples were lysated with MagNA Lyser (Roche, Burges Hill, UK) prior to DNA extraction. DNA extraction was performed with PowerMicrobiome ${ }^{\mathrm{Tm}}$ RNA isolation kit (MO BIO, Carlsbad, CA, USA) following the manufacturer's instructions with some modifications, such as omitting the $\beta$-mercaptoethanol and DNase I steps. The concentration of the extracted prokaryotic DNA in each sample was calculated by qPCR with 926F [14] and 1027R [15] primers at a concentration of $0.4 \mu \mathrm{mol} / \mathrm{L}$ in iQ SYBRgreen Supermix qPCR (Bio-Rad Laboratories Inc., Hercules, CA, USA). PCR was carried out with Universal primers 341F-785R of V3-V4 regions to amplify $16 \mathrm{~S}$ rRNA in a dual-index sequencing strategy according to [16] with Taq KAPA HiFi Hotstart ReadyMix (Kapa Biosystems, Woburn, MA, USA) and $12.5 \mathrm{ng}$ bacterial DNA to reduce PCR bias. Four PCR products from the same sample were pooled before cleaning up step with QIAquick Gel Extraction Kit (Qiagen, Hilden, Germany). Negative controls and MOCK communities were included in the sequencing as controls. The library was sequenced on an Illumina HiSeq platform $2 \times 300$ paired end. All reagents used were molecular grade. 
High-throughput sequencing and bioinformatics analysis Raw fastq files were imported, demultiplexed and processed using QIIME 2 (version 2018.6) [17]. Paired-ends fastq files were quality filtered and dereplicated with DADA2 [18]. Alpha and beta diversity were calculated under rooted phylogeny downsampling to the lowest count of sequences. Taxonomy was assigned to the resulting 16S rRNA marker genes against the SILVA (version 132) 99\% OTUs (trained with naive-bayes for $341 \mathrm{~F}-785 \mathrm{R}$ region of the $16 \mathrm{~S}$ ) using sklearn classifier method to determine the taxonomy according to Bokulich et al. [19]. Chloroplast and mitochondria were considered as contamination and removed from the otus biom table, as well as low frequency OTUs $(<10$ reads in $<5$ samples), previously to statistical analysis.

\section{Statistical analysis}

The pen was the experimental unit for all parameters. Growth performance data were analysed according to the $2 \times 2$ factorial design using the MIXED procedure in SAS software (version 2012, SAS Institute Inc. Cary, NC, USA). The model included source and level and feeding phase as fixed effects. The different time points were included as repeated measures. The carcass and breast meat yield were subjected to the GLIMMIX procedure in SAS. Post hoc analysis was done using Tukey. R in QIIME2 (version 2018.6) was used to analyse alpha diversity with KruskalWallis and Spearman for correlations, beta diversity with
PERMANOVA and ANOSIM with a sequencing depth of 234,000 and 175,000 sequences for ileum and cecum, respectively. Taxonomy data was analysed with LEfSE [20] and represented in RDA plots with Canoco. Microbiota results were analysed comparing the four treatments, and in addition the main effects of mineral source and level were explored. The results were considered being significantly different when $P<0.05$.

\section{Results \\ Growth performance and carcass characteristics}

Growth performance results are shown in Table 3. At day 27 of the study, birds fed HTM had a significantly $(P=0.0229)$ higher body weight than birds fed STM, regardless of mineral levels. This continued until day 34 as a strong trend $(P=0.0542)$ towards an increased body weight in birds fed HTM compared to birds fed STM. Average daily gain (ADG) and average daily feed intake (ADFI) followed the same patterns as body weight throughout the study. In this case, between 10 and 27 days a tendency was observed towards an increased ADG $(P=0.0738)$ and ADFI $(P=0.0846)$ for birds fed HTM compared to birds fed STM. However, this tendency resulted in a significantly improved ADG $(P=$ $0.0130)$ and ADFI $(P=0.0125)$ over the entire period for HTM fed birds compared to STM fed birds, regardless of mineral level. As a result, the feed conversion ratio (FCR) was not significantly different among treatments.

Table 3 Body weight (BW), average daily gain (ADG), average daily feed intake (ADFI) and feed conversion ratio (FCR) of the birds fed with the experimental diets (hydroxychloride trace minerals, HTM and sulphate trace minerals, STM) in high and low dosages ( \pm standard error)

\begin{tabular}{|c|c|c|c|c|c|c|c|c|}
\hline & \multirow[b]{2}{*}{ Day } & \multicolumn{2}{|l|}{ STM } & \multicolumn{2}{|l|}{ HTM } & \multicolumn{3}{|l|}{$P$-value } \\
\hline & & High & Low & High & Low & Source & Level & Sourcex Level \\
\hline \multirow[t]{4}{*}{ BW, g } & 0 & $43.2 \pm 0.2$ & $43.2 \pm 0.1$ & $43.5 \pm 0.3$ & $43.2 \pm 0.2$ & 0.3240 & 0.3747 & 0.4937 \\
\hline & 10 & $275.7 \pm 4.1$ & $278.2 \pm 2.0$ & $277.6 \pm 3.0$ & $279.1 \pm 2.0$ & 0.5471 & 0.3927 & 0.7652 \\
\hline & 27 & $1774.0 \pm 12.7$ & $1787.4 \pm 12.2$ & $1810.2 \pm 168$ & $1806.1 \pm 9.9$ & 0.0229 & 0.6872 & 0.1112 \\
\hline & 34 & $2463.7 \pm 13.5$ & $2476.0 \pm 15.3$ & $2506.9 \pm 21.6$ & $2493.1 \pm 18.3$ & 0.0542 & 0.9657 & 0.2137 \\
\hline \multirow[t]{4}{*}{ ADG, g/(bird.d) } & $0-10$ & $23.3 \pm 0.4$ & $23.5 \pm 0.2$ & $23.4 \pm 0.3$ & $23.6 \pm 0.2$ & 0.6950 & 0.4004 & 0.8352 \\
\hline & $10-27$ & $88.2 \pm 0.6$ & $88.8 \pm 0.6$ & $90.2 \pm 0.8$ & $89.8 \pm 0.5$ & 0.0738 & 0.8970 & 0.3155 \\
\hline & $27-34$ & $98.7 \pm 0.8$ & $98.3 \pm 0.9$ & $99.5 \pm 1.2$ & $98.2 \pm 1.4$ & 0.7133 & 0.4015 & 0.7773 \\
\hline & $0-34$ & $71.0 \pm 0.4$ & $71.6 \pm 0.5$ & $72.5 \pm 0.6$ & $72.2 \pm 0.5$ & 0.0130 & 0.7071 & 0.3407 \\
\hline \multirow[t]{4}{*}{ ADFl, g/(bird.d) } & $0-10$ & $25.1 \pm 0.4$ & $25.2 \pm 0.3$ & $25.1 \pm 0.4$ & $25.4 \pm 0.3$ & 0.6246 & 0.4419 & 0.7749 \\
\hline & $10-27$ & $121.2 \pm 0.8$ & $122.0 \pm 0.9$ & $123.4 \pm 1.2$ & $123.8 \pm 1.0$ & 0.0846 & 0.6205 & 0.3499 \\
\hline & $27-34$ & $156.8 \pm 1.8$ & $157.0 \pm 1.1$ & $158.3 \pm 1.0$ & $156.0 \pm 1.7$ & 0.8866 & 0.4835 & 0.7457 \\
\hline & $0-34$ & $99.8 \pm 0.6$ & $100.6 \pm 0.6$ & $101.5 \pm 0.8$ & $101.5 \pm 0.7$ & 0.0125 & 0.4312 & 0.4505 \\
\hline \multirow[t]{4}{*}{ FCR } & $0-10$ & $1.088 \pm 0.007$ & $1.071 \pm 0.001$ & $1.073 \pm 0.015$ & $1.078 \pm 0.012$ & 0.7182 & 0.6065 & 0.7631 \\
\hline & $10-27$ & $1.374 \pm 0.006$ & $1.374 \pm 0.004$ & $1.369 \pm 0.004$ & $1.378 \pm 0.006$ & 0.9621 & 0.6985 & 0.9611 \\
\hline & $27-34$ & $1.590 \pm 0.020$ & $1.597 \pm 0.010$ & $1.593 \pm 0.016$ & $1.591 \pm 0.026$ & 0.8683 & 0.8420 & 0.9797 \\
\hline & $0-34$ & $1.406 \pm 0.008$ & $1.406 \pm 0.034$ & $1.402 \pm 0.005$ & $1.407 \pm 0.008$ & 0.7415 & 0.6981 & 0.6875 \\
\hline
\end{tabular}


Table 4 Carcass yield and breast meat yield of the birds fed with the experimental diets (hydroxychloride trace minerals, HTM and sulphate trace minerals, STM) in high and low dosages

\begin{tabular}{|c|c|c|c|c|c|c|c|}
\hline & \multicolumn{2}{|l|}{ STM } & \multicolumn{2}{|l|}{ HTM } & \multicolumn{3}{|l|}{$P$-value } \\
\hline & High & Low & High & Low & Source & Level & SourcexLevel \\
\hline Carcass yield, $\%$ of body weight & $66.8 \pm 0.19$ & $66.5 \pm 0.22$ & $67.2 \pm 0.22$ & $66.9 \pm 0.29$ & 0.1239 & 0.1956 & 0.8997 \\
\hline Breast meat yield, $\%$ of carcass weight & $27.8 \pm 0.21$ & $27.3 \pm 0.23$ & $28.1 \pm 0.23$ & $27.4 \pm 0.26$ & 0.3906 & 0.0171 & 0.5172 \\
\hline
\end{tabular}

$P$-values below 0.1 are bolded

The effect of the treatments on carcass and breast meat yield were measured at the end of the study (Table 4). No significant differences were found in carcass yield. Breast meat yield was significantly higher in birds fed $80 \mathrm{mg} / \mathrm{kg} \mathrm{Zn}$ compared to birds fed $20 \mathrm{mg} /$ $\mathrm{kg} \mathrm{Zn}(P=0.0171)$, while no significant differences were found between the sources or any sourcexlevel interaction.

\section{Mineral content in ileal and cecal digesta}

The mineral content in the digesta from ileum and cecum is shown in Table 5. Birds fed HTM had significantly higher $\mathrm{Cu}$ contents in the ileum compared to the birds fed STM $(P=0.004)$. The Zn content in the ileum was proportional to the dietary $\mathrm{Zn}$ level, where birds fed a high dietary $\mathrm{Zn}$ presented significantly higher $\mathrm{Zn}$ than in birds fed low $\mathrm{Zn}(P<0.0001)$. In the cecum, the $\mathrm{Cu}$ level remained similar across the treatments, while $\mathrm{Zn}$ content depended significantly on the supplemented levels $(P<0.0001)$. Surprisingly, there was a significant sourcexlevel interaction where birds fed 80 and $20 \mathrm{mg} /$ $\mathrm{kg} \mathrm{Zn}$ from HTM showed the highest and the lowest cecum values, respectively $(P=0.0472)$.

\section{Microbiota}

In total, 42,854,714 sequences were obtained after removal of chloroplast and mitochondria reads (6046 sequences). Rarefactions curves of observed OTUs showed a plateau (Fig. 1) and good coverage values close to 1 from 20,000 sequences $(0.9999 \pm 0.0001)$, showing that sampling depth for all the members of the microbial communities were sampled. Alpha and beta diversity showed a clear (and significant) separation between the ileum and cecum (data not shown).

In the ileum, 23,998,507 sequences were recovered $(521,707 \pm 174,002$ sequences) representing 100 OTUs. Beta diversity ordination represented by redundancy analysis (Fig. 1) showed significant distances on ANOSIM $(P=0.020)$ and PERMANOVA $(P=0.014)$ of unweighted unifrac and a trend in jaccard $(P=0.080)$, between microbial communities in the ileum of birds fed $80 \mathrm{mg} / \mathrm{kg} \mathrm{Zn}$ from HTM to birds fed $20 \mathrm{mg} / \mathrm{kg}$ from HTM. The STM fed birds showed intermediate values not differing from any of the other treatments tested. The number of observed OTUs of alpha diversity was significantly higher in the group fed $80 \mathrm{mg} / \mathrm{kg} \mathrm{Zn}$ from HTM $(50 \pm 14.1)$ than $20 \mathrm{mg} / \mathrm{kg}$ Zn from HTM (39 \pm 8.3) $(P=0.049)$, as well as the phylogenetic distances, whereas both STM groups were in-between (Table 6). In addition, Spearman correlations showed a tendency towards a positive correlation between the number of observed species in the ileum and the breast meat yield $(P=0.093)$ (data not shown). The taxonomy at phyla level (data not shown) showed Firmicutes as main phyla (99.8\%), followed by Actinobacteria (0.15\%), Proteobacteria $(0.08 \%)$ and Patescibacteria $(0.01 \%)$. Actinobacteria phyla was significantly higher in group fed $80 \mathrm{mg} / \mathrm{kg} \mathrm{Zn}$ from HTM $(0.34 \%)$ in comparison with the group fed $20 \mathrm{mg} / \mathrm{kg} \mathrm{Zn}$ from HTM $(0.03 \%)(P=0.043)$. At genus

Table 5 Mineral contents in ileal and cecal digesta at day 34 of the birds fed with the experimental diets (hydroxychloride trace minerals, HTM and sulphate trace minerals, STM) in high and low dosages

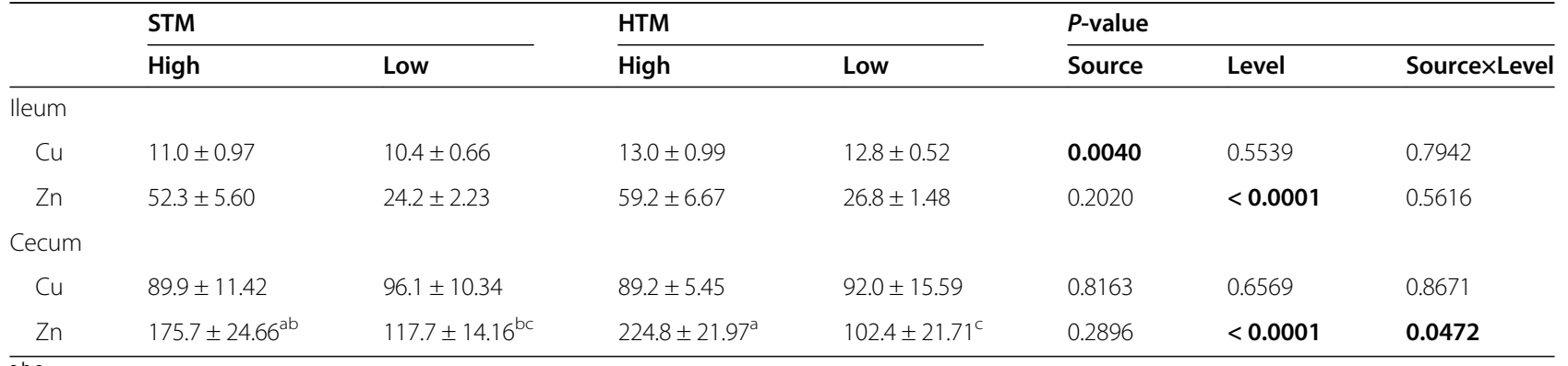

$\bar{a}, \mathrm{~b}, \mathrm{c}$ different superscripts inside of each row represent significant differences among treatments based on the sourcexlevel interaction effect $(P<0.05)$. $P$-values below 0.1 are bolded 


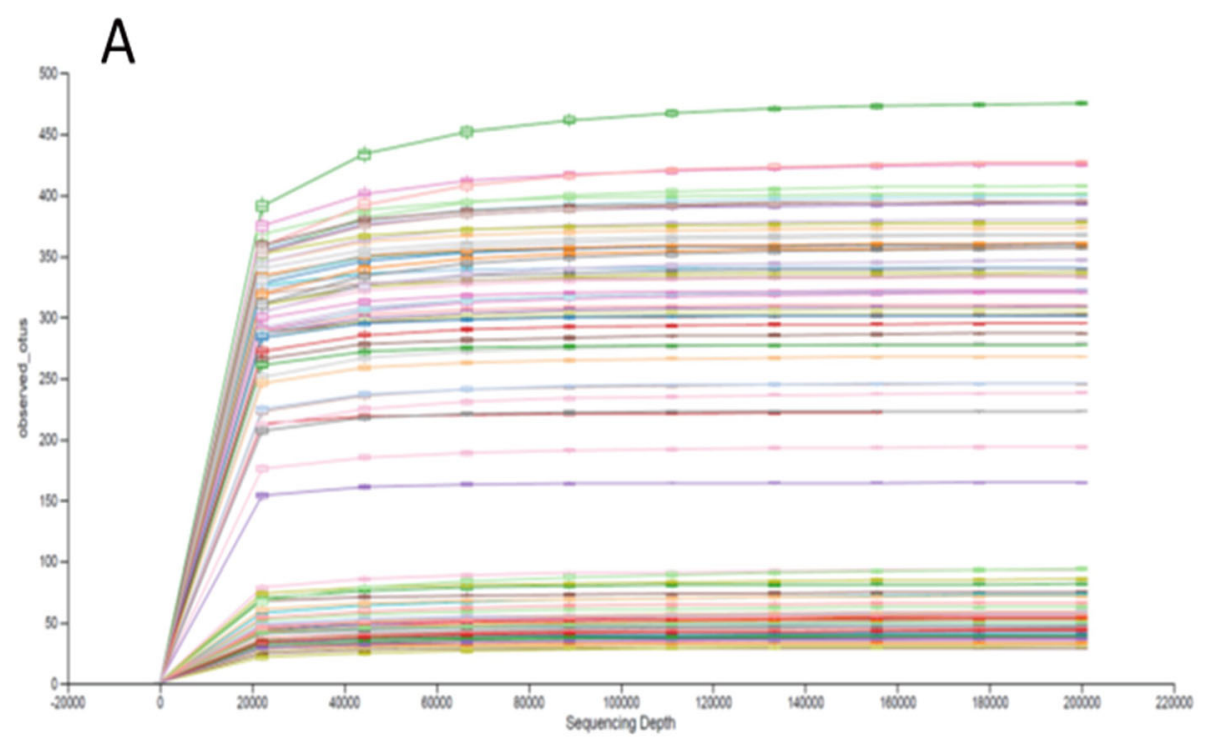

B

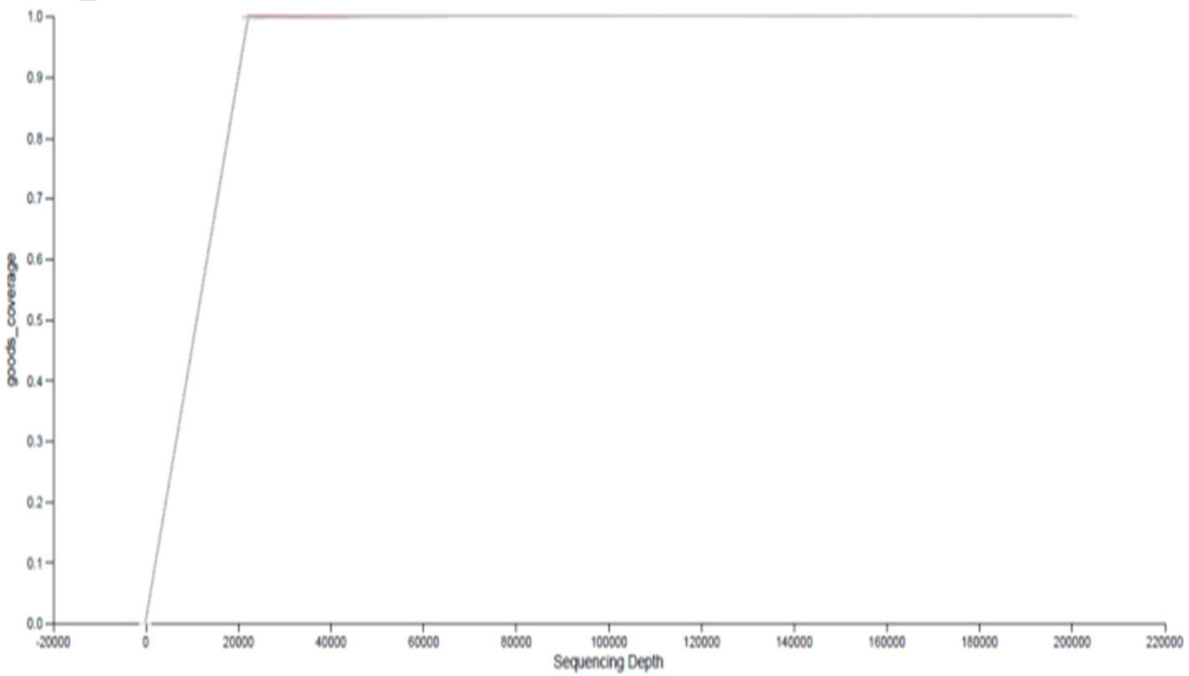

Fig. 1 Alpha rarefaction of observed OTUs (a) and good coverages (b) in all the samples at day 34

level, the main organism present in the ileum was Lactobacillus (> 88\%) (Table 7).

Differences in the remaining genera in the ileum are shown in Table 7 and visualized in Fig. 2. The different areas show that the diet containing $80 \mathrm{mg} / \mathrm{kg} \mathrm{Zn}$ from HTM permitted some diversity strength in the ileum at day 34. The arrows in Fig. 2 show significantly increased Enterococcus $(P=0.012)$ and Streptococcus $(P=0.042)$, in comparison to the diet containing $20 \mathrm{mg} / \mathrm{kg} \mathrm{Zn}$ from STM, which in turn presented higher Lactobacillus than $80 \mathrm{mg} / \mathrm{kg} \mathrm{Zn}$ from HTM $(P=0.010)$. The group fed 80 $\mathrm{mg} / \mathrm{kg}$ Zn from HTM also presented higher Bifidobacterium $(P=0.018)$, Blautia $(P=0.034)$, Streptococcus $(P=0.043)$, Weissella $(P=0.039)$, Eubacterium hallii group $(P=0.033)$, Ruminococcus torques $g(P=0.043)$ than the group fed $20 \mathrm{mg} / \mathrm{kg}$ Zn from HTM (Table 7). Dosage levels (20 versus $80 \mathrm{mg} / \mathrm{kg}$ ) presented significant differences of abundance in Lactobacillus $(20 \mathrm{mg} / \mathrm{kg})$ and in Streptococcus and Enterococcus $(80 \mathrm{mg} / \mathrm{kg})$, mainly because of the high influence of the group fed $80 \mathrm{mg} / \mathrm{kg} \mathrm{Zn}$ from HTM. No significant difference was found by the overall source effect, regardless of $\mathrm{Zn}$ level.

In the cecum, 17,250,171 sequences were recovered $(359,379 \pm 111,998$ sequences) representing 644 OTUs. Beta diversity ordination represented by redundancy analysis (Fig. 3) showed significant distances in ANOSIM per source of the unweighted unifrac and jaccard distances $(P=0.019$ and $P=0.027$, respectively), promoted 
Table 6 Alpha diversity parameters in the ileum and cecum $(n=12)$ at day 34 of the birds fed with the experimental diets (hydroxychloride trace minerals, HTM and sulphate trace minerals, STM) in high and low dosages

\begin{tabular}{|c|c|c|c|c|c|c|}
\hline Gut section & Source & Level & Observed_OTUS & Shannon & Evenness & Faith_pd \\
\hline \multirow[t]{4}{*}{ lleum } & \multirow[t]{2}{*}{ STM } & High & $43 \pm 10^{\mathrm{ab}}$ & $2.6 \pm 0.6$ & $0.48 \pm 0.09$ & $4.0 \pm 0.8^{\mathrm{ab}}$ \\
\hline & & Low & $44 \pm 9^{\mathrm{ab}}$ & $2.3 \pm 0.6$ & $0.43 \pm 0.13$ & $4.1 \pm 1.2^{\mathrm{ab}}$ \\
\hline & \multirow[t]{2}{*}{ HTM } & High & $50 \pm 14^{a}$ & $2.8 \pm 0.6$ & $0.50 \pm 0.11$ & $4.4 \pm 0.9^{a}$ \\
\hline & & Low & $39 \pm 8^{b}$ & $2.5 \pm 0.5$ & $0.48 \pm 0.09$ & $3.6 \pm 0.7^{b}$ \\
\hline \multirow[t]{2}{*}{$P$-value main effects } & & Source & 0.8602 & 0.3557 & 0.4680 & 0.7085 \\
\hline & & Level & 0.1133 & 0.1440 & 0.4100 & 0.1112 \\
\hline \multirow[t]{4}{*}{ Cecum } & \multirow[t]{2}{*}{ STM } & High & $288 \pm 62$ & $5.6 \pm 0.4^{b}$ & $0.69 \pm 0.03$ & $18 \pm 2^{b}$ \\
\hline & & Low & $308 \pm 67$ & $5.8 \pm 0.4^{\mathrm{ab}}$ & $0.70 \pm 0.03$ & $19 \pm 2^{\mathrm{ab}}$ \\
\hline & \multirow[t]{2}{*}{ HTM } & High & $312 \pm 41$ & $5.9 \pm 0.3^{\mathrm{ab}}$ & $0.71 \pm 0.03$ & $19 \pm 1^{\mathrm{ab}}$ \\
\hline & & Low & $327 \pm 29$ & $6.0 \pm 0.2^{\mathrm{a}}$ & $0.71 \pm 0.02$ & $20 \pm 1^{a}$ \\
\hline \multirow[t]{2}{*}{$P$-value main effects } & & Source & 0.3588 & 0.0665 & 0.0990 & 0.3025 \\
\hline & & Level & 0.1270 & 0.3325 & 0.7887 & 0.0696 \\
\hline
\end{tabular}

a,b Different superscripts inside of each column represents significant differences among treatments per region based on pairwise comparisons $(P<0.05)$. $P$-values below 0.1 are bolded

by significant differences between both groups fed $20 \mathrm{mg} /$ $\mathrm{kg} \mathrm{Zn}(P=0.007$ and $P=0.031$, respectively). Feeding 20 $\mathrm{mg} / \mathrm{kg} \mathrm{Zn}$ from HTM also presented marked differences in the ANOSIM and PERMANOVA of unweighted unifrac distances in comparison with feeding $80 \mathrm{mg} / \mathrm{kg} \mathrm{Zn}$ from $\operatorname{HTM}(P=0.014$ and $P=0.011$, respectively) or from STM $(P=0.011$ and $P=0.022$, respectively). The alpha diversity confirmed the differences found in the ordination of the bacterial communities (see Table 6). The Shannon index, an indication for population diversity, shows a tendency towards a higher diversity in the HTM fed groups compared to the STM groups $(P=0.066)$, with the group fed $80 \mathrm{mg} / \mathrm{kg} \mathrm{Zn}$ from STM having the lowest diversity in comparison with the group fed $20 \mathrm{mg} / \mathrm{kg} \mathrm{Zn}$ from HTM $(P=0.049)$. The observed species in the cecum tended to be higher in birds fed $20 \mathrm{mg} / \mathrm{kg}$ Zn from HTM compared to the birds fed $80 \mathrm{mg} / \mathrm{kg} \mathrm{Zn}$ from STM $(P=0.067)$. The evenness showed a trend towards an increased $(P=$ 0.099) richness in the HTM groups compared to the STM groups, regardless of Zn level. Taking the phylogenetic distances into account, the Faith_PD parameter did show a trend towards a different community in the groups fed $20 \mathrm{mg} / \mathrm{kg} \mathrm{Zn}$ compared to the groups fed $80 \mathrm{mg} / \mathrm{kg} \mathrm{Zn}(P=0.070)$, and specifically between $20 \mathrm{mg} / \mathrm{kg} \mathrm{Zn}$ from HTM and $80 \mathrm{mg} / \mathrm{kg} \mathrm{Zn}$ from STM $(P=0.024)$ (Table 6). In addition, significant positives correlations were found between the carcass yield and Shannon $(P=0.0322)$, evenness $(P=0.046)$ or observed species (trend, $P=0.062)$ in the cecum. Also the ADFI and ADG performance indexes tended to be positively correlated to the richness or evenness of the microbiota $(P=0.053$ and $P=0.098$, respectively) (data not shown).
The taxonomy in the cecum presented as the main phylum Firmicutes (87.3\%), Actinobacteria (9.5\%), Bacteroidetes (3.1\%), and in less extend Proteobacteria $(0.06 \%)$, Tenericutes $(0.05 \%)$ and Cyanobacteria $(0.01 \%)$. On family level, the main taxa present in the cecum were the Lachnospiraceae, Ruminococcaceae, Lactobacillaceae and Bifidobacteriaceae.

At genus level, the main organisms present in the cecum were Lactobacillus, Faecalibacterium, unknown genus from Lachnospiraceae family, Bifidobacterium, several Ruminococcus groups, Butyricoccus, Blautia and Alistipes (Table 8 and Fig. 3). Being $80 \mathrm{mg} / \mathrm{kg}$ the most common commercial level used in broiler feed the most interesting comparison would be between groups fed $80 \mathrm{mg} / \mathrm{kg} \mathrm{Zn}$ from either STM or HTM. In this case, significant differences were found in Streptococcus and two unidentified genus from the family vadin BB60 being higher in birds fed $80 \mathrm{mg} / \mathrm{kg}$ Zn from HTM than from STM. Only CHKCIOO2 from Eggerthellaceae family presented higher values in birds fed $80 \mathrm{mg} / \mathrm{kg}$ $\mathrm{Zn}$ from STM than from HTM. As in the ileum, the majority of the significant differences were in between HTM groups (Table 8). The group fed $20 \mathrm{mg} /$ $\mathrm{kg}$ Zn from HTM contained higher relative abundances of Blautia, Anaerostipes, Christensenellaceae R-7 group, Ruminococcus 1, Ruminococcaceae UCG004, Tyzzerella, Eubacterium nodatum group, Ruminococcaceae_uncultured, Family XIII (AD3011 and UCG-001 groups), Eubacterium brachy group, Pygmaiobacter, Peptococcaceae_other, whereas the group fed $80 \mathrm{mg} / \mathrm{kg}$ Zn from HTM showed significantly higher relative amounts of vadin BB60 group 
Table 7 Genus composition of the ileum at day $35(n=12)$ at day 34 of the birds fed with the experimental diets (hydroxychloride trace minerals, HTM and sulphate trace minerals, STM) in high $(80 \mathrm{mg} / \mathrm{kg})$ and low $(20 \mathrm{mg} / \mathrm{kg})$ dosages

\begin{tabular}{|c|c|c|c|c|}
\hline & \multicolumn{2}{|l|}{ STM } & \multicolumn{2}{|l|}{ HTM } \\
\hline & High & Low & High & Low \\
\hline Lactobacillus & $92.2 \pm 9.5^{\mathrm{ab}}$ & $98.0 \pm 3.8^{\mathrm{a}}$ & $88.8 \pm 11.08^{b}$ & $96.2 \pm 7.97^{\mathrm{ab}}$ \\
\hline Enterococcus & $6.10 \pm 8.60^{\mathrm{ab}}$ & $0.852 \pm 2.24^{b}$ & $7.7 \pm 8.2^{\mathrm{a}}$ & $3.08 \pm 7.29^{\mathrm{ab}}$ \\
\hline Streptococcus & $0.743 \pm 0.868^{\mathrm{ab}}$ & $0.429 \pm 1.01^{b}$ & $2.4 \pm 3.5^{\mathrm{a}}$ & $0.385 \pm 0.800^{b}$ \\
\hline Candidatus Arthromitus & $0.647 \pm 1.354$ & $0.316 \pm 0.534$ & $0.113 \pm 0.170$ & $0.288 \pm 0.544$ \\
\hline Corynebacterium 1 & $0.071 \pm 0.084$ & $0.127 \pm 0.133$ & $0.250 \pm 0.342$ & $0.018 \pm 0.016$ \\
\hline Staphylococcus & $0.050 \pm 0.063$ & $0.078 \pm 0.098$ & $0.378 \pm 0.603$ & $0.024 \pm 0.019$ \\
\hline Escherichia-Shigella & $0.073 \pm 0.142$ & $0.033 \pm 0.076$ & $0.197 \pm 0.477$ & $0.015 \pm 0.018$ \\
\hline Weissella & $0.006 \pm 0.010^{\mathrm{ab}}$ & $0.023 \pm 0.045^{\mathrm{ab}}$ & $0.021 \pm 0.030^{a}$ & $0.001 \pm 0.001^{b}$ \\
\hline Bifidobacterium & $0.007 \pm 0.008^{\mathrm{ab}}$ & $0.014 \pm 0.016^{\mathrm{ab}}$ & $0.039 \pm 0.053^{\mathrm{a}}$ & $0.008 \pm 0.015^{b}$ \\
\hline Brachybacterium & $0.026 \pm 0.065$ & $0.025 \pm 0.042$ & $0.037 \pm 0.080$ & $0.000 \pm 0.000$ \\
\hline Aerococcus & $0.010 \pm 0.033$ & $0.017 \pm 0.034$ & $0.011 \pm 0.017$ & $0.000 \pm 0.000$ \\
\hline Clostridium sensu stricto 1 & $0.018 \pm 0.050$ & $0.004 \pm 0.007$ & $0.018 \pm 0.057$ & $0.004 \pm 0.011$ \\
\hline Blautia & $0.001 \pm 0.001^{\mathrm{ab}}$ & $0.003 \pm 0.006^{\mathrm{ab}}$ & $0.007 \pm 0.009^{a}$ & $0.001 \pm 0.002^{b}$ \\
\hline Dietzia & $0.000 \pm 0.001$ & $0.002 \pm 0.004$ & $0.002 \pm 0.004$ & $0.000 \pm 0.000$ \\
\hline Brevibacterium & $0.007 \pm 0.021$ & $0.006 \pm 0.015$ & $0.007 \pm 0.019$ & $0.000 \pm 0.000$ \\
\hline Ruminococcus torques $g$ & $0.001 \pm 0.002^{\mathrm{ab}}$ & $0.003 \pm 0.003^{\mathrm{ab}}$ & $0.004 \pm 0.005^{\mathrm{a}}$ & $0.002 \pm 0.006^{b}$ \\
\hline Faecalibacterium & $0.001 \pm 0.001$ & $0.004 \pm 0.006$ & $0.002 \pm 0.003$ & $0.003 \pm 0.009$ \\
\hline Pediococcus & $0.001 \pm 0.001$ & $0.000 \pm 0.000$ & $0.002 \pm 0.004$ & $0.000 \pm 0.002$ \\
\hline Lachnospiraceae_unknown & $0.002 \pm 0.004$ & $0.001 \pm 0.003$ & $0.003 \pm 0.005$ & $0.000 \pm 0.001$ \\
\hline Jeotgalicoccus & $0.006 \pm 0.017$ & $0.008 \pm 0.013$ & $0.009 \pm 0.016$ & $0.000 \pm 0.000$ \\
\hline Facklamia & $0.001 \pm 0.003$ & $0.001 \pm 0.003$ & $0.002 \pm 0.005$ & $0.000 \pm 0.000$ \\
\hline Eubacterium hallii $g$ & $0.000 \pm 0.000^{\mathrm{ab}}$ & $0.000 \pm 0.001^{\mathrm{ab}}$ & $0.001 \pm 0.001^{\mathrm{a}}$ & $0.000 \pm 0.000^{b}$ \\
\hline Anaerostipes & $0.000 \pm 0.000$ & $0.000 \pm 0.000$ & $0.000 \pm 0.000$ & $0.000 \pm 0.001$ \\
\hline CAG-56 & $0.000 \pm 0.000$ & $0.000 \pm 0.000$ & $0.000 \pm 0.001$ & $0.000 \pm 0.001$ \\
\hline Sellimonas & $0.000 \pm 0.001$ & $0.000 \pm 0.001$ & $0.001 \pm 0.002$ & $0.000 \pm 0.002$ \\
\hline Saccharimonadales_unknown & $0.000 \pm 0.001$ & $0.001 \pm 0.002$ & $0.000 \pm 0.000$ & $0.000 \pm 0.000$ \\
\hline Paracoccus & $0.000 \pm 0.000$ & $0.000 \pm 0.001$ & $0.000 \pm 0.000$ & $0.000 \pm 0.000$ \\
\hline
\end{tabular}

a,b Different superscripts inside of each row represents significant differences among treatments $(P<0.05)$

(Table 8). The group fed $20 \mathrm{mg} / \mathrm{kg} \mathrm{Zn}$ from STM reached the highest Anaerotruncus level, Tyzzerella 3, Family XIII UCG-001, and Brachybacterium, and the group fed $80 \mathrm{mg} / \mathrm{kg} \mathrm{Zn}$ from STM the highest CHKCIOO2 (Table 8). Dosage level $20 \mathrm{mg} / \mathrm{kg}$ presented higher significant abundance of Anaerostipes, Pygmaiobacter, unknown genus from Peptococcaceae family, Christensenellaceae R-7 group and family XIII in comparison with $80 \mathrm{mg} / \mathrm{kg}$ when analysed using the LEfSe approach [20]. This result is mainly cause by the high influence of the HTM20 group. Source (HTM vs. STM) also changed the microbial composition of the cecum. In this case, HTM groups had an increased abundance of Streptococcus and Enteroccocaceae family, and STM groups of family vadin BB60 group and unknown genus from Christensenellaceae family.

\section{Discussion}

The current study tested the effect of STM compared to HTM on the growth performance, carcass characteristics and gut microbiota of broiler chickens. In this comparison two different $\mathrm{Zn}$ levels from STM were compared to the same levels of $\mathrm{Zn}$ from HTM. In all diets the same level of $15 \mathrm{mg} / \mathrm{kg}$ added $\mathrm{Cu}$ was used in the same source as the $\mathrm{Zn}$. Due to the combined use of $\mathrm{Zn}$ and $\mathrm{Cu}$ of each source, the observed effects can not directly be linked to either $\mathrm{Zn}$ or $\mathrm{Cu}$. Vieira [21] described a possible interaction between $\mathrm{Zn}$ and $\mathrm{Cu}$ via competition for the same carrier and due to their interaction with 

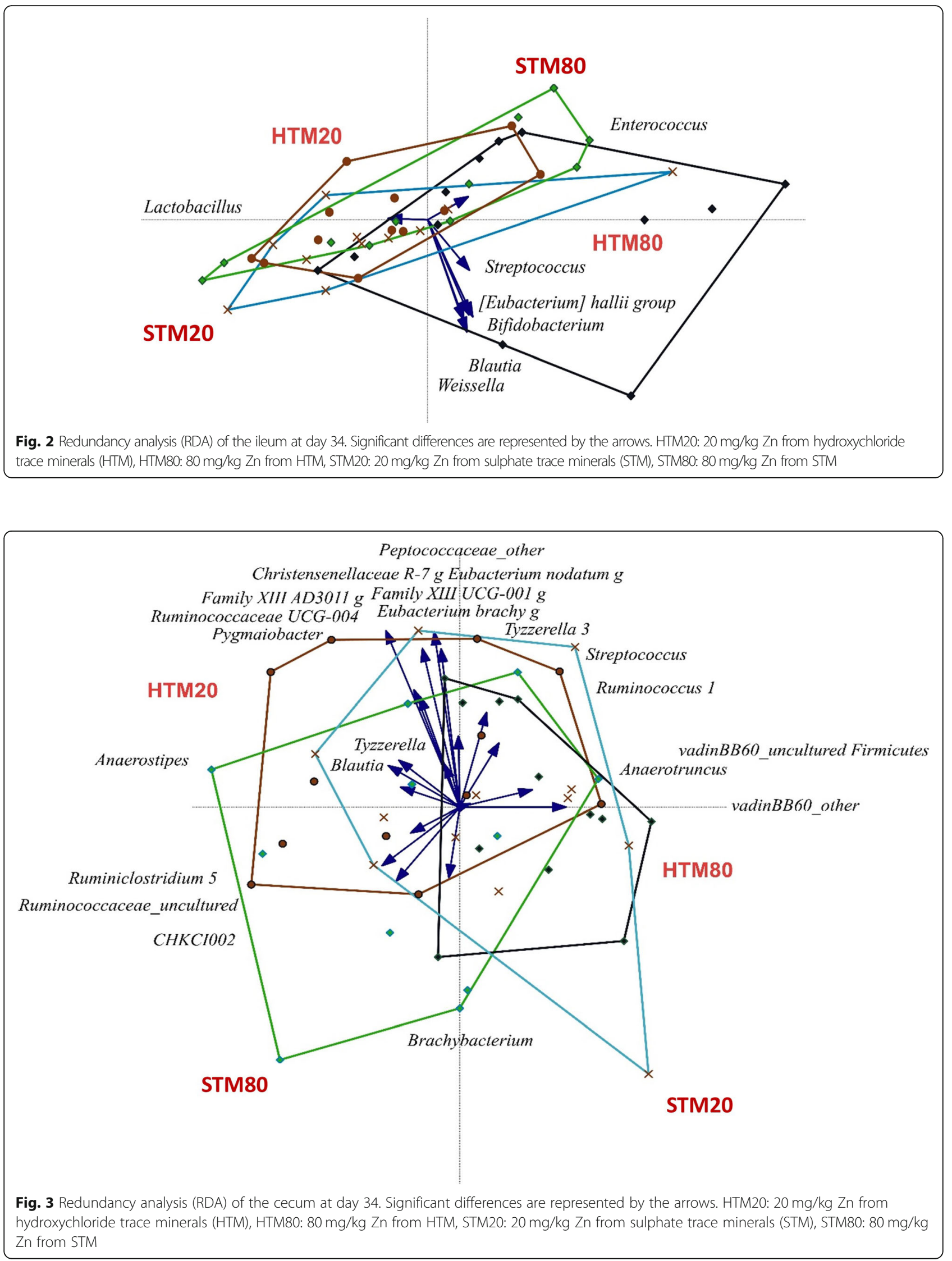
Table 8 Genera composition of the cecum higher than 1\% relative abundance and genera presenting significant differences at day $34(n=12)$ of the birds fed with the experimental diets (hydroxychloride trace minerals, HTM and sulphate trace minerals, STM) in high $(80 \mathrm{mg} / \mathrm{kg})$ and low $(20 \mathrm{mg} / \mathrm{kg})$ dosages

\begin{tabular}{|c|c|c|c|c|}
\hline & \multicolumn{2}{|l|}{ STM } & \multicolumn{2}{|l|}{ HTM } \\
\hline & High & Low & High & Low \\
\hline Lactobacillus & $17.6 \pm 5.70$ & $17.1 \pm 8.50$ & $17.9 \pm 5.50$ & $14.7 \pm 5.00$ \\
\hline Lachnospiraceae_other & $14.0 \pm 3.30$ & $15.4 \pm 4.40$ & $15.4 \pm 4.60$ & $12.1 \pm 3.40$ \\
\hline Bifidobacterium & $11.5 \pm 6.80$ & $9.20 \pm 7.40$ & $7.90 \pm 4.10$ & $9.90 \pm 5.10$ \\
\hline Faecalibacterium & $10.0 \pm 6.70$ & $12.7 \pm 6.60$ & $14.1 \pm 5.90$ & $12.3 \pm 4.90$ \\
\hline Ruminococcus torques g & $8.40 \pm 5.40$ & $6.60 \pm 2.90$ & $7.20 \pm 3.50$ & $8.50 \pm 5.20$ \\
\hline Blautia & $6.30 \pm 3.30^{\mathrm{ab}}$ & $6.30 \pm 4.30^{\mathrm{ab}}$ & $4.70 \pm 1.40^{\mathrm{b}}$ & $7.70 \pm 3.10^{\mathrm{a}}$ \\
\hline Ruminococcaceae_other & $4.50 \pm 1.70$ & $3.70 \pm 1.00$ & $4.20 \pm 1.40$ & $4.50 \pm 1.40$ \\
\hline Ruminococcaceae UCG-014 & $3.70 \pm 2.60$ & $4.10 \pm 3.20$ & $4.70 \pm 1.40$ & $3.80 \pm 1.80$ \\
\hline Butyricicoccus & $2.90 \pm 1.80$ & $3.50 \pm 2.20$ & $3.50 \pm 2.40$ & $3.40 \pm 1.40$ \\
\hline Alistipes & $2.90 \pm 2.00$ & $3.10 \pm 2.20$ & $2.70 \pm 2.20$ & $2.70 \pm 1.90$ \\
\hline Ruminiclostridium 5 & $2.50 \pm 1.80^{\mathrm{ab}}$ & $0.900 \pm 0.500^{b}$ & $1.90 \pm 1.50^{\mathrm{ab}}$ & $2.20 \pm 1.10^{\mathrm{a}}$ \\
\hline Anaerostipes & $1.80 \pm 2.00^{\mathrm{ab}}$ & $2.00 \pm 1.30^{\mathrm{ab}}$ & $1.10 \pm 0.500^{b}$ & $2.20 \pm 1.20^{\mathrm{a}}$ \\
\hline Sellimonas & $1.50 \pm 1.10$ & $1.10 \pm 0.400$ & $1.00 \pm 0.500$ & $1.50 \pm 0.600$ \\
\hline Eubacterium hallii $\mathrm{g}$ & $1.40 \pm 1.10$ & $1.90 \pm 1.30$ & $1.10 \pm 0.700$ & $1.50 \pm 0.900$ \\
\hline Dorea & $1.30 \pm 1.60$ & $1.20 \pm 1.30$ & $1.60 \pm 1.70$ & $2.10 \pm 1.70$ \\
\hline Clostridiales_other & $1.00 \pm 0.700$ & $1.10 \pm 0.900$ & $1.00 \pm 0.500$ & $1.50 \pm 0.800$ \\
\hline Eubacterium coprostanoligenes & $0.930 \pm 0.570$ & $1.20 \pm 0.700$ & $0.750 \pm 0.470$ & $0.940 \pm 0.590$ \\
\hline Subdoligranulum & $0.900 \pm 0.790$ & $1.20 \pm 1.20$ & $1.50 \pm 1.00$ & $0.990 \pm 0.620$ \\
\hline Firmicutes_other & $0.790 \pm 0.680$ & $1.00 \pm 1.00$ & $1.10 \pm 1.20$ & $0.540 \pm 0.550$ \\
\hline Christensenellaceae R-7 g & $0.210 \pm 0.250^{b}$ & $0.280 \pm 0.250^{b}$ & $0.220 \pm 0.320^{b}$ & $0.630 \pm 0.470^{a}$ \\
\hline Streptococcus & $0.160 \pm 0.230^{b}$ & $0.380 \pm 0.570^{\mathrm{ab}}$ & $0.870 \pm 1.280^{\mathrm{a}}$ & $0.500 \pm 0.720^{\mathrm{ab}}$ \\
\hline Ruminococcus 1 & $0.200 \pm 0.340^{\mathrm{ab}}$ & $0.170 \pm 0.300^{a b}$ & $0.110 \pm 0.170^{b}$ & $0.270 \pm 0.260^{a}$ \\
\hline Ruminococcaceae UCG-004 & $0.180 \pm 0.100^{\mathrm{ab}}$ & $0.180 \pm 0.120^{\mathrm{ab}}$ & $0.160 \pm 0.090^{b}$ & $0.260 \pm 0.070^{a}$ \\
\hline CHKCIOO2 & $0.210 \pm 0.080^{\mathrm{a}}$ & $0.130 \pm 0.110^{b}$ & $0.130 \pm 0.060^{b}$ & $0.160 \pm 0.060^{\mathrm{ab}}$ \\
\hline Tyzzerella & $0.140 \pm 0.160^{\mathrm{ab}}$ & $0.090 \pm 0.120^{b}$ & $0.060 \pm 0.060^{b}$ & $0.180 \pm 0.100^{a}$ \\
\hline vadinBB60_uncultured & $0.030 \pm 0.040^{b}$ & $0.190 \pm 0.480^{\mathrm{ab}}$ & $0.060 \pm 0.060^{\mathrm{a}}$ & $0.060 \pm 0.100^{\mathrm{ab}}$ \\
\hline Anaerotruncus & $0.030 \pm 0.030^{\mathrm{ab}}$ & $0.060 \pm 0.050^{\mathrm{a}}$ & $0.020 \pm 0.010^{b}$ & $0.030 \pm 0.060^{\mathrm{ab}}$ \\
\hline Tyzzerella 3 & $0.010 \pm 0.010^{b}$ & $0.030 \pm 0.020^{\mathrm{a}}$ & $0.020 \pm 0.010^{a b}$ & $0.020 \pm 0.010^{\mathrm{ab}}$ \\
\hline Eubacterium nodatum g & $0.010 \pm 0.010^{\mathrm{ab}}$ & $0.020 \pm 0.020^{\mathrm{ab}}$ & $0.010 \pm 0.010^{b}$ & $0.020 \pm 0.010^{a}$ \\
\hline Ruminococcaceae_uncultured & $0.010 \pm 0.014^{\mathrm{ab}}$ & $0.004 \pm 0.006^{\mathrm{ab}}$ & $0.001 \pm 0.001^{b}$ & $0.006 \pm 0.006^{a}$ \\
\hline Family XIII AD3011 g & $0.009 \pm 0.008^{\mathrm{ab}}$ & $0.009 \pm 0.006^{\mathrm{ab}}$ & $0.009 \pm 0.008^{b}$ & $0.022 \pm 0.008^{\mathrm{a}}$ \\
\hline Eubacterium brachy g & $0.007 \pm 0.011^{b}$ & $0.015 \pm 0.023^{\mathrm{ab}}$ & $0.010 \pm 0.017^{b}$ & $0.032 \pm 0.018^{\mathrm{a}}$ \\
\hline vadinBB60_other & $0.006 \pm 0.015^{b}$ & $0.009 \pm 0.018^{b}$ & $0.031 \pm 0.020^{\mathrm{a}}$ & $0.004 \pm 0.005^{b}$ \\
\hline Pygmaiobacter & $0.006 \pm 0.014^{b}$ & $0.007 \pm 0.009^{a b}$ & $0.005 \pm 0.009^{b}$ & $0.074 \pm 0.150^{a}$ \\
\hline Family XIII UCG-001 g & $0.004 \pm 0.007^{b}$ & $0.014 \pm 0.011^{\mathrm{a}}$ & $0.006 \pm 0.007^{b}$ & $0.017 \pm 0.009^{a}$ \\
\hline vadinBB60_uncultured Firm. & $0.004 \pm 0.008^{\mathrm{ab}}$ & $0.008 \pm 0.018^{\mathrm{ab}}$ & $0.014 \pm 0.012^{\mathrm{a}}$ & $0.004 \pm 0.007^{b}$ \\
\hline Brachybacterium & $0.003 \pm 0.012^{\mathrm{ab}}$ & $0.004 \pm 0.011^{\mathrm{a}}$ & $0.001 \pm 0.003^{\mathrm{ab}}$ & $0.000 \pm 0.000^{b}$ \\
\hline Peptococcaceae_other & $0.001 \pm 0.001^{\mathrm{ab}}$ & $0.002 \pm 0.006^{\mathrm{ab}}$ & $0.000 \pm 0.001$ & $0.002 \pm 0.003^{\mathrm{a}}$ \\
\hline
\end{tabular}

\footnotetext{
$\mathrm{a}, \mathrm{b}$ Different superscripts inside of each row represents significant differences among treatments $(P<0.05)$
} 
phytate and calcium. At the relatively low levels of $\mathrm{Cu}$ used in the current study no differences between the mineral sources are expected. Therefore, the focus of the discussion is on $\mathrm{Zn}$, while the possible interaction effect of $\mathrm{Cu}$ should be kept in mind.

This study showed a beneficial effect of HTM on growth performance, specifically on body weight and average daily gain. The breast meat yield was not influenced by mineral source, however only by $\mathrm{Zn}$ level with higher $\mathrm{Zn}$ resulting in a higher breast meat yield. This is in contrast to the differences reported by Olukosi et al. [13], who described a beneficial effect of HTM over STM and a beneficial effect of $20 \mathrm{mg} / \mathrm{kg}$ over $80 \mathrm{mg} / \mathrm{kg}$ $\mathrm{Zn}$. In that study, the carcass results were correlated with the growth performance results, which was not the case in the current study. Olukosi et al. [13] observed an improved gain:feed in the overall study period in the birds fed HTM compared to STM, regardless of mineral level. In the current study, feeding HTM resulted in a higher gain, but due to the increased feed intake, FCR was not significantly different. The main difference between Olukosi et al.'s study [13] and the current study could be the presence of non-starch polysaccharide (NSP) degrading enzymes in the current diet, which had a higher wheat content. High wheat diets are often challenging gut health due to the high viscosity [22, 23]. Adding NSP enzymes to the diet in the current study may have caused a lower viscosity, thus a less challenging condition in the gut. These results suggested that the trace mineral sources tested here could likely behave differently in their physiological effect in the gastrointestinal tract (GIT). The $\mathrm{Zn}$ contents in ileal and cecal digesta seemed to confirm this different behaviour by the two mineral sources. The main difference was observed in the cecum between the birds fed either 80 or $20 \mathrm{mg} / \mathrm{kg} \mathrm{Zn}$ from HTM. The higher Zn level in the cecum in the birds fed $80 \mathrm{mg} / \mathrm{kg} \mathrm{Zn}$ from HTM suggested more available $\mathrm{Zn}$ later in the intestine. Although the role of the cecum in $\mathrm{Zn}$ uptake is not described yet, it is known that most controlled uptake of $\mathrm{Zn}$ takes place in the ileum [24]. Not only more $\mathrm{Zn}$ is present, HTM are also defined as more bioavailable for the animal compared to STM [7]. Another important characteristic of HTM is related to their crystalline structure [25]. This structure results in a low solubility above $\mathrm{pH} 4$ [9], possibly leading to a more gradual release throughout the gastrointestinal tract. As a result, more minerals are available later in the intestine of HTM-fed birds. This study confirmed that more $\mathrm{Zn}$ was present in the lower part of the gastrointestinal tract when $80 \mathrm{mg} / \mathrm{kg}$ HTM was fed. The absorption of $\mathrm{Zn}$ was not measured in this study, so the uptake could not be confirmed. In the $20 \mathrm{mg} / \mathrm{kg} \mathrm{Zn}$ groups it may be expected that the body reserves for minerals were not exceeded, resulting in less excretion of $\mathrm{Zn}$ back into the intestine via the gallbladder. With a higher bioavailability of HTM, less $\mathrm{Zn}$ would be expected in the gut contents in birds fed $20 \mathrm{mg} / \mathrm{kg} \mathrm{Zn}$ from HTM compared to $20 \mathrm{mg} / \mathrm{kg} \mathrm{Zn}$ from STM. The difference in $\mathrm{Zn}$ content of digesta may also explain the differences observed in microbiota analysis. In addition, the higher $\mathrm{Cu}$ content in both HTM treatment groups in the ileum indicate that by changing the source of both $\mathrm{Zn}$ and $\mathrm{Cu}$ may have synergistic effects on the birds. Future studies should focus on identifying possible interaction and synergistic effects of $\mathrm{Cu}$ and $\mathrm{Zn}$ and the influence of mineral sources on this.

Generally, the main organism present in the ileum was Lactobacillus. This is in line with the study of Munyaka et al. [23], who also described Lactobacillus to be the most abundant species in the ileum of birds fed high fiber diets. In the cecum the main species on family level were Lachnospiraceae, Ruminococcaceae, Lactobacillaceae and Bifidobacteriaceae. This is in line with Munyaka et al. [23], who observed Lachnospiraceae as the main family in the cecum. In addition to Lachnospiraceae, other families of the Clostridia such as Clostridiaceae and Ruminococcaceae are identified as main organisms in the cecum [26].

The current study shows indications for an improved richness and evenness in the diversity of cecal microbiota in birds fed HTM. In the literature, $\mathrm{Zn}$ is described to be important for microbiota diversity, since chronic $\mathrm{Zn}$ deficiency is related to a reduced species richness and diversity in the cecum [27]. Moreover, Gielda and DiRita [12] and Reed et al. [27] also revealed the importance of $\mathrm{Zn}$ for a proper microbiota functioning. In the present study, even though $\mathrm{Zn}$ levels were above current recommendations for broiler chickens the source of $\mathrm{Zn}$ also showed an important effect in this sense. The current results suggest that HTM is more available for both the animal, based on the performance results, and for the microbiota, based on the species diversity results.

A difference in microbiota may also be related to the growth performance of broiler chickens. Stanley et al. [28] showed a different cecal microbial community between high and low performing birds in terms of FCR. Although they suggested that cellulose and resistant starch degrading organisms were linked with high performing birds, most species could not be identified. The increase of Blautia, a fiber degrading organism, in ileal digesta of birds fed $80 \mathrm{mg} / \mathrm{kg}$ Zn from HTM may support this hypothesis. It is unknown whether the other different species observed in the current study may be responsible for the difference in growth performance, however the positive correlation of carcass yield and ADFI trend with Shannon and evenness indexes could support this fact. 
Change in specific species of the microbiota may not always lead to a clear conclusion. For example, Clostridia are commonly found in the cecum of chickens, as shown both in laying hens and broilers [29, 30]. Similarly, Streptococcus species have been found in the cecum of broiler chickens [29], and depending on the species and abundance, these organisms could be beneficial for the birds. An increase in these organisms may be either beneficial or harmful. For some organisms such as Weissella, which was increased in the ileum of birds fed 80 $\mathrm{mg} / \mathrm{kg} \mathrm{Zn}$ from HTM, it is known that Zn has a promoting effect on it. Vahjen et al. [31] observed an increase in Weissella in the ileal digesta of pigs fed high levels of $\mathrm{ZnO}$, showing that high $\mathrm{Zn}$ may increase the presence of this bacteria in the intestinal content.

Interestingly, most of the differences were observed between the groups fed 80 or $20 \mathrm{mg} / \mathrm{kg}$ Zn from HTM, whereas the STM groups reached values in between. This might suggest that HTM is able to modulate the gut microbiota in both sections of the intestine studied.

\section{Conclusions}

Birds fed diets containing $\mathrm{Cu}$ and Zn from HTM performed better than birds fed minerals from STM. In the overall study, the ADG and ADFI were significantly higher in the HTM fed birds. Also a tendency towards an increased body weight was observed in HTM fed birds. This did not result in differences in carcass yield and breast meat yield. The microbial diversity in the ileum and cecum were higher in the HTM fed birds compared to the STM fed birds. Main differences in the bacterial composition were found in the cecum, especially between the group fed $80 \mathrm{mg} / \mathrm{kg}$ Zn from HTM and $20 \mathrm{mg} / \mathrm{kg} \mathrm{Zn}$ from HTM. These were the two groups with the highest contrast in $\mathrm{Zn}$ levels in the cecum. Further, the main taxonomical differences found in the cecum were in between the two groups fed 80

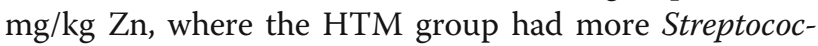
cus and two unidentified genus from vadin BB60 family and less CHKCIOO2 from Eggerthellaceae family, than the STM group. Therefore, results from this study show that HTM can clearly modulate the microbiota, increase bacterial diversity in the GIT and potentially increase the growth performance in chickens.

\section{Acknowledgements}

Not applicable.

\section{Authors' contributions}

Study set up, execution: SvK, AIGR, YH; Data analysis: SvK, AR; writing, reviewing and editing manuscript: SVK, YH, AIGR, AR. All authors read and approved the final manuscript.

\section{Funding}

No external funding was obtained for this study.

\section{Availability of data and materials}

The datasets used during the current study are available from the corresponding author on reasonable request.

\section{Ethics approval and consent to participate}

Animal procedures were verified by the External Ethical Committee of "Hospital General Universitario de Ciudad Real", and approved by the Junta de Castilla-La Mancha Animal Welfare department as compliable with the RD $53 / 2013$ of the 1 st of February which establishes basic rules applied to protect animals used for research, and other scientific matters like teaching. The regulations conform to the European Directive 2010/63/EU for the Protection of Vertebrate Animals Used for Experimental and Other Scientific Purposes (Brussels, European Union) and achieve the standard of care required by the US Department of Health and Human Services' Guide for the Care and Use of Laboratory Animals.

Consent for publication

Not applicable.

\section{Competing interests}

The authors declare that they have no competing interests.

\section{Author details}

${ }^{1}$ Trouw Nutrition R\&D, P.O. Box 299, 3800, AG, Amersfoort, the Netherlands.

${ }^{2}$ Trouw Nutrition R\&D, 45950 Casarrubios del Monte, Toledo, Spain.

Received: 26 August 2020 Accepted: 11 January 2021

Published online: 09 March 2021

\section{References}

1. Salim HM, Jo C, Lee BD. Zinc in broiler feeding and nutrition. Avian Biol Res. 2008;1(1):5-18.

2. Prasad AS. Zinc: role in immunity, oxidative stress and chronic inflammation. Curr Opin Clin Nutr Metab Care. 2009;12:646-52.

3. National Research Council. 1994. Nutrient Requirements of Poultry. 9th rev. ed. Natl. Acad. Press, Washington, DC.

4. EFSA FEEDAP Panel (EFSA panel on additives and products or substances used in animal feed). Scientific opinion on the potential reduction of the currently authorized maximum zinc content in complete feed. EFSA J 2014; 12(5):3668-3745.

5. Bao YM, Choct M, lji PA, Bruerton K. Effect of organically complexed copper, iron, manganese, and zinc on broiler performance, mineral excretion, and accumulation in tissues. J Appl Poult Res. 2007;16:448-55.

6. Wedekind $\mathrm{KJ}$, Hortin AE, Baker DH. Methodology for assessing zinc bioavailability: efficacy estimates for zinc-methionine, zinc sulfate and zinc oxide. J Anim Sci. 1992;70:178-87.

7. Batal AB, Parr TM, Baker DH. Zinc bioavailability in tetrabasic zinc chloride and the dietary zinc requirement of young chicks fed a soy concentrate diet. Poult Sci. 2001;80:87-90.

8. Miles RD, O'Keefe SF, Henry PR, Ammerman CB, Luo XG. The effect of dietary supplementation with copper sulfate or tribasic copper chloride on broiler performance, relative copper bioavailability, and dietary prooxidant activity. Poult Sci. 1998;77:416-25

9. Villagómez-Estrada S, Pérez JF, van Kuijk S, Melo-Durán D, Karimirad R, SolàOriol D. Effect of two zinc supplementation levels and two zinc and copper sources with different solubility characteristics on the growth performance, carcass characteristics and digestibility of growing-finishing pigs. J Anim Physiol Nutr. 2020;00:1-13.

10. Luo XG, Ji F, Lin YX, Steward FA, Lu L, Liu B, et al. Effects of dietary supplementation with copper sulfate or tribasic copper chloride on broiler performance, relative copper bioavailability, and oxidation stability of vitamin E in feed. Poult Sci. 2005:84:888-93.

11. Lu L, Wang RL, Zhang ZJ, Steward FA, Luo X, Liu B. Effect of dietary supplementation with copper sulfate or tribasic copper chloride on the growth performance, liver copper concentrations of broilers fed in floor pens, and stabilities of vitamin E and phytase in feed. Bio Trace Elem Res. 2010;138:181-9.

12. Gielda LM, DiRita VJ. Zinc competition among the intestinal microbiota. mBio 2012;3(4):00171-00112. 
13. Olukosi OA, van Kuijk S, Han Y. Copper and zinc sources and levels of zinc inclusion influence growth performance, tissue trace mineral content, and carcass yield of broiler chickens. Poult Sci. 2018;97:3891-8.

14. De Gregoris TB, Aldred N, Clare AS, Burgess JG. Improvement of phylumand class-specific primers for real-time PCR quantification of bacterial taxa. J Microbiol Methods Volume. 2011;86(3):351-6.

15. Claesson MJ, O'Sullivan O, Wang Q, Nikkilä J, Marchesi JR, Smidt H, et al. Comparative analysis of pyrosequencing and a phylogenetic microarray for exploring microbial community structures in the human distal intestine. PLoS One. 2009;4(8):e6669.

16. Kozich JJ, Westcott SL, Baxter NT, Highlander SK, Schloss PD. Development of a dual-index sequencing strategy and curation pipeline for analyzing amplicon sequence data on the MiSeq Illumina sequencing platform. App Environ Microbiol. 2013;79(17):5112-20.

17. Bolyen E, Rideout JR, Dillon MR, Bokulich NA, Abnet CC, Al-Ghalith GA, et al. QIIME 2: reproducible, interactive, scalable, and extensible microbiome data science. Preprints. 2019;27295.

18. Callahan BJ, McMurdie PJ, Rosen MJ, Han AW, Johnson AJA, Holmes SP. DADA2: high-resolution sample inference from Illumina amplicon data. Nat Methods 2016;13:581-583.

19. Bokulich NA, Kaehler BD, Rideout JR, Dillon M, Bolyen E, Knight R, et al. Optimizing taxonomic classification of marker-gene amplicon sequences with QIIIME 2's q2-feature-classifier plugin. Microbiome. 2018;6(1):90.

20. Segata N, lzard J, Waldron L, Gevers D, Miropolsky L, Garrett WS, et al. Metagenomic biomarker discovery and explanation. Genome Biol 2011; 12(6): R60. Published 2011 Jun 24. doi:https:/doi.org/10.1186/gb-2011-12-6-r60.

21. Vieira SL. Chelated minerals for poultry. Braz J Poultry Sci. 2008;10(2):73-9.

22. Choct M. Enzymes for the feed industry: past, present and future. World's Poult Sci J. 2006;62:5-16.

23. Munyaka PM, Nandha NK, Kiarie E, Nyachoti CM, Khafipour E. Impact of combined $\beta$-glucanase and xylanase enzymes on growth performance, nutrients utilization and gut microbiota in broiler chickens fed corn or wheat-based diets. Poult Sci. 2016:95:528-40.

24. Yu Y, Lu L, Luo XG, Liu B. Kinetics of zinc absorption by in situ ligated intestinal loops of broilers involved in zinc transporters. Poult Sci. 2008;87: $1146-55$.

25. Hawthorne FC, Sokolova E. Simonkolleite, $\mathrm{Zn} 5(\mathrm{OH}) 8 \mathrm{Cl} 2(\mathrm{H} 2 \mathrm{O})$, a decorated interrupted-sheet structure of the form [M 42$] 4$. Can Mineral. 2002;40:939-46.

26. Pourabedin $M$, Zhao X. Prebiotics and gut microbiota in chickens. FEMS Microbiol Lett. 2015;362(15):fnv122. https://doi.org/10.1093/femsle/fnv122.

27. Reed S, Neuman H, Moscovich S, Glahn RP, Koren O, Tako E. Chronic zinc deficiency alters chick gut microbiota composition and function. Nutrients. 2015;7:9768-84.

28. Stanley D, Denman SE, Hughes RJ, Geier MS, Crowley TN, Chen H, et al. Intestinal microbiota associated with differential feed conversion efficiency in chickens. Appl Microbiol Biotechnol. 2012;96:1361-9.

29. Rehman HU, Vahjen W, Awad WA, Zentek J. Indigenous bacteria and bacterial metabolic products in the gastrointestinal tract of broiler chickens. Archives Anim Nutr. 2007;61(5):319-35.

30. Lan PTN, Hayashi H, Sakamoto M, Benno Y. Phylogenetic analysis of cecal microbiota in chicken by the use of $165 \mathrm{rDNA}$ clone libraries. Microbiol Immunol. 2002;46(6):371-82.

31. Vahjen W, Pieper R, Zentek J. Bar-coded pyrosequencing of $16 \mathrm{~S}$ rRNA gene amplicons reveals changes in ileal porcine bacterial communities due to high dietary zinc intake. Appl Environ Microbiol. 2010;76(19):6689-91.

Ready to submit your research? Choose BMC and benefit from:

- fast, convenient online submission

- thorough peer review by experienced researchers in your field

- rapid publication on acceptance

- support for research data, including large and complex data types

- gold Open Access which fosters wider collaboration and increased citations

- maximum visibility for your research: over $100 \mathrm{M}$ website views per year

At BMC, research is always in progress.

Learn more biomedcentral.com/submissions 